ISSN: 1907-9931 (print), 2476-9991 (online)

\title{
DESAIN DAN MANUFAKTUR MINI CIRCULATING WATER CHANNEL TANK UNTUK PENGUJIAN PROTOTYPE KAPAL GUNA MENGETAHUI KARAKTERISTIK HIDRODINAMIKA LAMBUNG KAPAL DAN PERILAKU GERAKAN KAPAL DESIGN AND MANUFACTURING OF MINI CIRCULATING WATER CHANNEL TANK FOR TESTING THE PROTOTYPE OF SHIP USING KNOWING CHARACTERISTICS OF HYDRODYNAMIC SHIP LAMPS AND BEHAVIOR OF SHIP MOVEMENT
}

\author{
Yeddid Yonatan Eka Darma*, Anggra Fiveriati, Galang Sandy Prayogo \\ Program Studi Teknik Manufaktur Kapal, Jurusan Teknik Mesin, Politeknik Negeri Banyuwangi \\ JI.Raya Jember KM 13 Labanasem Kecamatan Kabat Kabupaten Banyuwangi \\ *Corresponding author-email: yeddidyonatan@poliwangi.ac.id
}

Submitted: 31 December 2020 / Revised: 04 June 2020 / Accepted: 27 July 2020

http://doi.org/ 10.21107/jk.v13i2.6243

\begin{abstract}
As a coastal area, Banyuwangi has a variety of marine potential that can be harness, both in terms of tourism and in terms of fishing. This certainly must be equipped with ships that the design are in accordance with the conditions of the Banyuwangi sea, and the special purpose of the ship. So it is become necessary to test hydrodynamic characteristic of the ship hull. Hydrodynamics testing is one of the engineering subject in the field of naval architecture technology. This field, studies the behavior of the object motion or ships hull that are in the water. The existence and movement of objects in water create a boundary layer where if the boundary layer is wider the consequence is resistance will increase, so that the ship's fuel consumption also increases. The hydrodynamic analysis in this study is based on the observation method of water flow generated by the ship's prototype, and the ship's maneuver conditions. For this reason, in this research, an experimental test equipment for fast boat (tourism) and fishing boat needs to be designed. The equipment is a Mini Circulating Water Channel Tank, this experimental device can help the design stages of fast boats and fishing boats before fabrication, so it is able to minimize design failure. Mini Circulating Water Channel Tank is designed with a length of about 3 meters and a height of 2 meters with a maximum flow speed of $4 \mathrm{~m} / \mathrm{s}$ and in the upper position will be given a special suspension clamp to provide a feasible simulation of ships sailing on the high seas, so as to provide data accurate regarding the condition of the hull and the behavior of the ship's movements.
\end{abstract}

Keywords: Mini Circulating Water Channel Tank, Hydrostatic Test.

\begin{abstract}
ABSTRAK
Sebagai daerah pesisir, Banyuwangi memiliki berbagai macam potensi laut yang bisa dimanfaatkan, baik itu dari segi pariwisata maupun dari segi penangkapan ikan. Hal ini tentu harus di lengkapi dengan kapal-kapal dengan desain yang sesuai dengan kondisi laut Banyuwangi dan tujuan khusus kapal tersebut. Sehingga diperlukannya pengujian hidrodinamis terhadap lambung kapal. Hidrodinamika atau pengujian hidrodinamis merupakan ilmu keteknikan di bidang teknologi perkapalan. Bidang ilmu ini mempelajari perilaku gerakan benda atau kapal yang berada di air. Keberadaan dan pergerakan benda di air menimbulkan apa yang disebut lapisan batas atau boundary layer dimana jika boundary layer semakin lebar maka konsekuensinya adalah besarnya hambatan tenaga penggerak sehingga konsumsi bahan bakar kapal meningkat. Analisa hidrodinamika pada penelitian ini didasarkan pada metode observasi aliran air yang di hasilkan oleh prototype kapal, dan kondisi manuver kapal. Untuk itu dalam penelitian ini, perlu dirancang sebuah peralatan eksperimen pengujian untuk kapal cepat (pariwisata) dan kapal nelayan. Peralatan tersebut adalah Mini Circulating Water Channel Tank, piranti percobaan ini dapat membantu tahap desain kapal cepat dan kapal nelayan sebelum fabrikasi, sehingga dapat meminimalkan kegagalan desain yang disebabkan oleh cacat pada lambung kapal. Mini Circulating Water Channel Tank dirancang dengan ukuran panjang sekitar 3 meter dan tinggi 2
\end{abstract}


meter dengan kecepatan aliran maksimal $4 \mathrm{~m} / \mathrm{s}$ dan di posisi atas akan di berikan penjepit bersuspensi khusus untuk memberikan simulasi layak nya kapal berlayar di lautan lepas, sehingga mampu memberikan data yang akurat mengenai kondisi lambung kapal dan perilaku gerakan kapal.

Kata Kunci: Mini Circulating Water Channel Tank, Uji Hidrodinamika Kapal.

\section{PENDAHULUAN}

Kabupaten Banyuwangi merupakan kabupaten terluas di Jawa Timur sekaligus menjadi yang terluas di Pulau Jawa, dengan luas wilayahnya yang mencapai $5.782,50 \mathrm{~km}^{2}$, atau lebih luas dari Pulau Bali $\left(5.636,66 \mathrm{~km}^{2}\right)$. Di bagian selatan Banyuwangi terdapat kawasan ekosistem hutan tropis yang menyimpan banyak pantai yang indah dan eksotik seperti pantai teluk hijau atau green land. Di bagian timur terdapat pulau Lombok yang penuh dengan wisata pantai yang menarik. Baik teluk hijau maupun pulau Lombok, memiliki posisi yang cukup sulit dijangkau oleh perjalanan darat, misalnya teluk hijau, pengunjung di haruskan mendaki bukit di sekitar teluk selama satu jam untuk mencapai ke lokasi, sedangkan pulau lombok harus melakukan perjalanan darat dan laut selama kurang lebih satu hari menggunakan perjalanan laut dari Banyuwangi menuju pulau Bali barat, dan perjalanan darat ke pulau Bali timur dan kemudian menyebrang ke pulau Lombok, sehingga perlu adanya sarana transportasi laut dengan kecepatan tinggi untuk mencapai lokasi-lokasi tersebut. Selain itu, sebagai daerah pesisir, Banyuwangi memiliki berbagai macam potensi laut yang bisa di manfaatkan, misalnya dari segi penangkapan ikan. Hal ini tentu harus di lengkapi dengan kapal-kapal dengan desain yang sesuai dengan kondisi laut Banyuwangi dan tujuan khusus kapal tersebut.

Pada setiap sarana transportasi laut, harus memperhatikan karakteristik lambung kapal yang tercelup di dalam air, karena pada dasarnya akan mempengaruhi kondisi kapal saat berlayar. Sehingga lambung kapal yang tercelup penuh harus mempunyai kualitas dan performansi yang baik. Untuk mengetahui karakteristik ini, maka perlu adanya penelitian hidrostatik kapal. Karena ukuran kapal yang cukup besar maka dalam penelitian ini di buatlah prototype kapal yang karakteristik lambung kapal nya sama dengan kapal aslinya.

Hidrodinamika atau pengujian hidrodinamis merupakan ilmu keteknikandi bidang teknologi perkapalan. Bidang ilmu ini mempelajari perilaku gerakan benda atau kapal yang berada di air. Keberadaan dan pergerakan benda di air menimbulkan apa yang disebut lapisan batas atau boundary layer dimana jika boundary layer semakin lebar maka konsekuensinya adalah besarnya hambatan tenaga penggerak sehingga konsumsi bahan bakar kapal meningkat. Analisa hidrodinamika pada penelitian ini didasarkan pada metode observasi aliran air yang di hasilkan oleh prototype kapal, dan kondisi manuver kapal.

Untuk itu dalam penelitian ini, perlu dirancang sebuah peralatan eksperimen pengujian untuk kapal cepat (pariwisata) dan kapal nelayan. Peralatan tersebut adalah Mini Circulating Water Channel Tank, Circulating water channel tank menyediakan lingkungan aliran yang terkendali dimana berbagai macam percobaan dapat dilakukan. Konsep dari circulating water channel tank mesirkulasikan air didalam chamber atau tangki sehingga tangki tersebut seperti aliran sungai yang mengalir. Circulating water channel tank ini digunakan untuk menganalisis hidrodinamika kapal yang rumit. Eksperimen kualitatif dan kuantitatif dilakukan untuk mengembangkan kapal cepat dan kapal nelayan yang lebih handal dan untuk meneliti masalah yang berkaitan dengan sistem penangkapan ikan (Kawashima, T, 1991).

Perbedaan diantara kedua tangki pengujian ini adalah jika towing tank dengan kereta penarik tidak memiliki aliran air, dan menggunakan simulasi pembuat ombak, sehingga jika kita ingin mendapatkan hasil percobaan harus menarik model kapal tersebut sejauh tangki towing, dimana tangki towing ini memiliki dimensi yang sangat panjang. Sedangkan circulating water tank memiliki aliran air sehingga kapal model tidak perlu ditarik atau bergerak sepanjang chamber, sehingga dapat memperpendek dimensi dari chamber. 


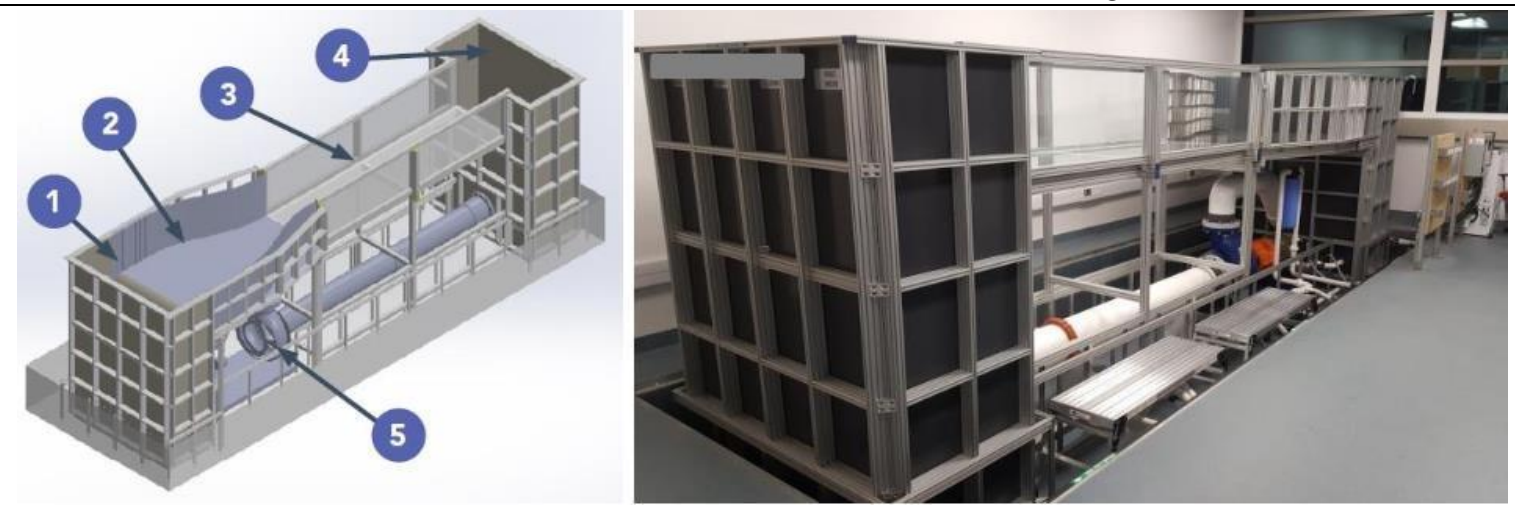

Gambar 1. Circulating Water Channel Tank (Pennsylvania State University Berks, 2017)

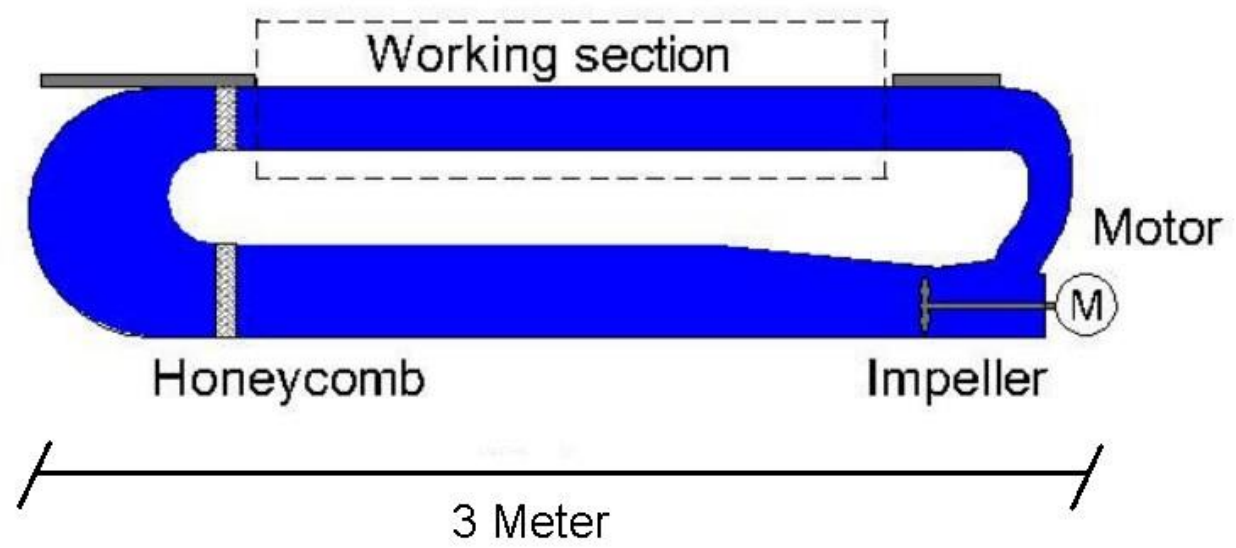

Gambar 2. Model of Mini Circulating Water Channel Tank (Luke Myers, Pascal Galloway, 2011)

Mini Circulating Water Channel Tank dirancang dengan ukuran panjang sekitar 3 meter lebar 1.5 meter dan tinggi 2 meter dengan kecepatan aliran maksimal $1 \mathrm{~m} / \mathrm{s}$ dan di posisi atas akan di berikan penjepit bersuspensi khusus untuk memberikan simulasi layak nya kapal berlayar di lautan lepas, sehingga mampu memberikan data yang akurat mengenai kondisi lambung kapal dan perilaku gerakan kapal.

\section{MATERI DAN METODE}

Penelitian dilakukan di Politeknik Negeri Banyuwangi pada periode Oktober 2019. Pembuatan alat dan pengambilan data dilakukan di workshop kapal kayu Teknik Manufaktur Kapal. Metode yang di gunakan untuk mendesain alat adalah finite element analysis. Analisa ini digunakan untuk menentukan material yang tepat pada test bed, karena test bed ini haruslah menggunakan material yang transparan dan kuat untuk menahan tekanan air. Untuk desain kapal sendiri menggunakan software maxsurf dengan mempertimbangkan kurva bonjean sebagai dasar penentuan desain kapal yang baik. Sedangkan untuk olah gerak kapal metode analisa yang di gunakan adalah observasi dari free surface wave analysis

\section{HASIL DAN PEMBAHASAN}

Desain yang di gunakan untuk alat ini adalah dengan membedakan diameter inlet dan outlet dari chamber itu sendiri dengan harapan aliran air dapat lebih cepat di bagian outlet. Asumsi ini diperkuat dengan analisa streamline. Gambar 3. 


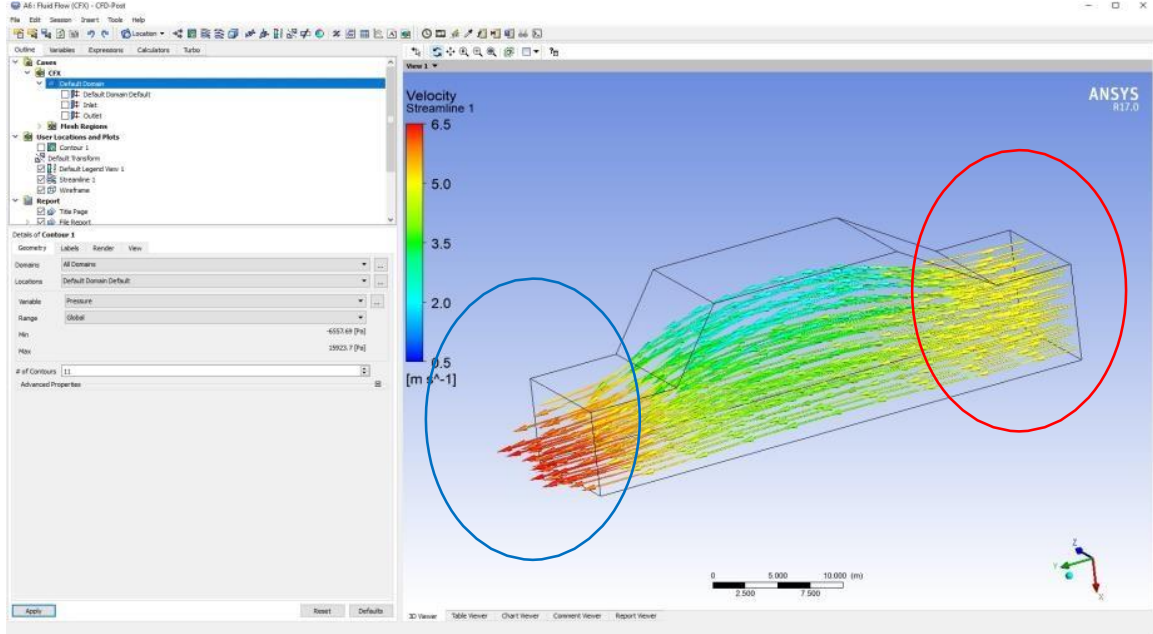

Gambar 3. Analisa Streamline pada Chamber

Hasil simulasi menunjukkan bahwa di sisi inlet (Lingkaran Merah) diberikan aliran air sekitar 5 $\mathrm{m} / \mathrm{s}$ dan terjadi penurunan aliran air saat berada di tengah atau di dalam test bed namun pada sisi outlet (Lingkaran Biru) terdapat kenaikan aliran maksimal $6.5 \mathrm{~m} / \mathrm{s}$. Hal ini menunjukkan bahwa desain chamber sudah sesuai dengan yang diinginkan sehingga proses desain di lanjutkan dengan menentukan material yang tepat untuk sisi test bed dengan menganalisa tekanan yang terjadi di sisi test bed.

Material di sisi test bed harus transparant agar memudahkan peneliti untuk melakukan analisa dan material mampu menahan tekanan air. Penentuan material di sisi test bed dilakukan dengan cara mensimulasikan tekanan pada chamber jika chamber di aliri air dengan kecepatan awal $5 \mathrm{~m} / \mathrm{s}$. Hasil simulasi tekanan pada chamber menunjukkan bahwa pada sisi inlet, tekanan pada dinding-dinding chamber sekitar 9179 Pascal atau 0.09179 Bar, dan pada sisi outlet tekanan pada dinding chamber sekitar 2434 Pascal atau 0.2434 Bar saja, hal ini menunjukkan pada bagian outlet meskipun terdapat kenaikan kecepatan aliran, di bagian outlet ini terdapat penurunan volume air. Hal ini di buktikan dengan adanya kontur yang berwarna biru tua yang menunjukkan tekanan di dinding chamber pada posisi tersebut di bawah 0 Pascal atau bisa di artikan bahwa pada dinding atas chamber tidak teraliri air yang berarti terdapat penurunan volume air.

Pada bagian test bed menunjukkan hal yang berbeda, terdapat kontur yang berwarna merah di bagian ini yang menunjukkan tekanan maksimal mencapai 15923 Pascal atau 0.15923 Bar (Gambar

4), oleh sebab itu peneliti menggunakan material transparant yang mampu menahan tekanan lebih dari $0.15923 \mathrm{Bar}$

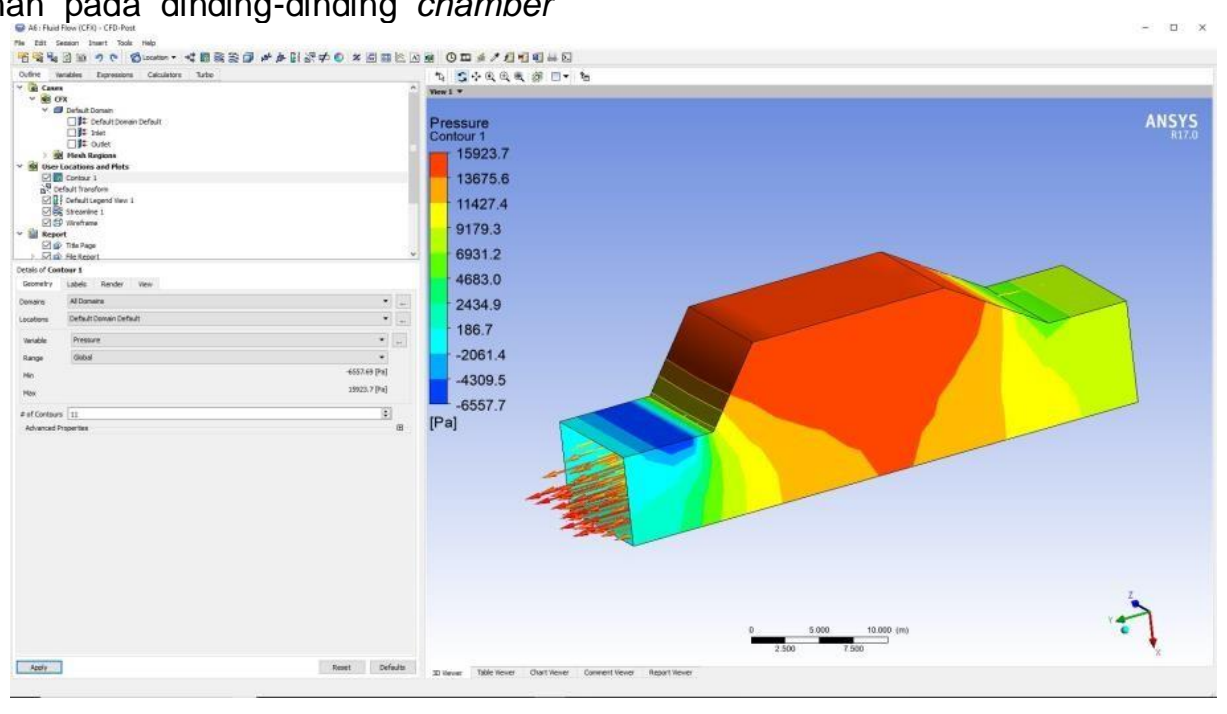

Gambar 4. Analisa Kontur pada Chamber 
Darma et al., Desain dan Manufaktur Mini Circculating Water

\section{Pemilihan Material Bagian Test Bed}

Pemilihan material di bagian test bed ini menngunakan data dari Pramudya Aditama,
2015. Mengatakan, bahwa kekuatan tekan akrilik tanpa ada nya tambahan fiber mencapai 56,27 MPa (Tabel 1). Oleh sebab itu penulis memilih bahan akrilik untuk test bed.

Tabel 1. Kekuatan Transversal dari Akrilik

\begin{tabular}{lrcc}
\hline \multicolumn{1}{c}{ Kelompok } & N & Rerata & Standar Deviasi \\
\hline Akrilik reinforced 3,7\% v/v polyethylene fiber & 5 & 67,77 & 3,34 \\
Akrilik reinforced 7,4\% v/v polyethylene fiber & 5 & 80,37 & 8,42 \\
Akrilik reinforced 3,7\% v/v E-glass fiber & 5 & 96,72 & 5,43 \\
Akrilik reinforced 7,4\% v/v E-glass fiber & 5 & 109,44 & 4,98 \\
Akrilik tanpa fiber & 5 & 56,27 & 4,70 \\
\hline
\end{tabular}

\section{Desain dan Pembuatan Prototype Kapal}

Desain dari kapal yang akan di analisa menggunakan sofrware maxsurf. Adapun

Tabel 2. DimensiUtama Kapal

\begin{tabular}{lcc}
\hline \multicolumn{1}{c}{ Parameter } & Nilai & Satuan \\
\hline Lenght Of Water Line (LWL) & 37.34 & $\mathrm{Cm}$ \\
Beam (Lebar Kapal) & 11.02 & $\mathrm{Cm}$ \\
Draft (Sarat Air) & 2 & $\mathrm{Cm}$ \\
Displacement Volume & 376.94 & $\mathrm{Cm}^{3}$ \\
\hline
\end{tabular}

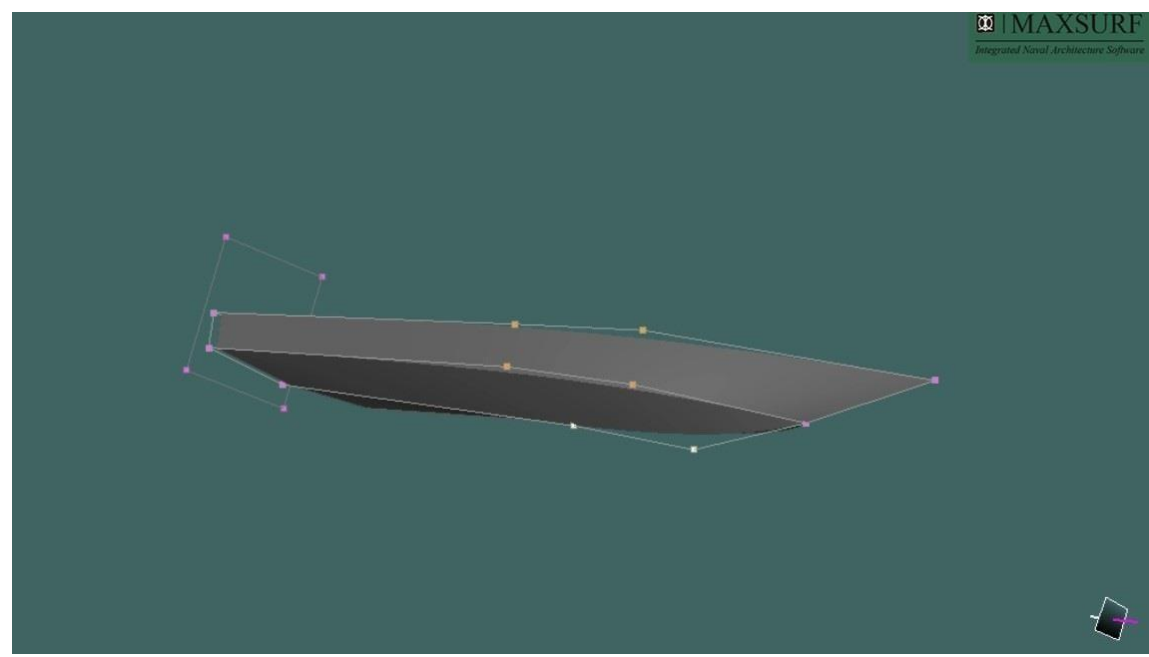

Gambar 5. Desain Kapal

\section{Karakteristik Hidrostatik Kapal}

Karakteristik hidrostatik kapal disajikan dalam bentuk kurva, Kurva hidrostatik ini menunjukan keadaan badan kapal dibawah garis air untuk tiap kenaikan sarat air. Adapun karakteristik hidrostatik kapal dapat dilihat di dimensi utama kapal yang di desain dapat di lihat di Tabel 2 sedangkan gambar desain dari kapal seperti pada Gambar 5
Gambar 6. Kurva ini di dapatkan dari mengukur keadaan kapal yang tercalup didalam air satupersatu sesuai dengan sarat air yang kita inginkan (Tabel 3).

Sarat air minimum yang di gunakan adalah $0.1 \mathrm{Cm}$ dan sarat air maksimum yang digunakan adalah $2 \mathrm{Cm}$. 
Jurnal Kelautan, 13(2), 67-74 (2020)

Tabel 3. Data Hidrostatik Kapal Model

\begin{tabular}{|c|c|c|c|c|c|c|c|c|c|c|}
\hline \multirow{2}{*}{ ITEM } & \multicolumn{10}{|c|}{ Draft of Ship $(\mathrm{Cm})$} \\
\hline & 0.1 & 0.31 & 0.52 & 0.73 & 0.94 & 1.16 & 1.37 & 1.58 & 1.79 & 2 \\
\hline Displacement kg & 0 & 0.0002 & 0.01 & 0.0351 & 0.0746 & 0.125 & 0.1837 & 0.2482 & 0.3164 & 0.3863 \\
\hline Heel deg & 0 & 0 & 0 & 0 & 0 & 0 & 0 & 0 & 0 & 0 \\
\hline Draft at FP cm & 0.1 & 0.31 & 0.52 & 0.73 & 0.94 & 1.16 & 1.37 & 1.58 & 1.79 & 2 \\
\hline Draft at $\mathrm{AP} \mathrm{cm}$ & 0.1 & 0.31 & 0.52 & 0.73 & 0.94 & 1.16 & 1.37 & 1.58 & 1.79 & 2 \\
\hline Draft at LCF cm & 0.1 & 0.31 & 0.52 & 0.73 & 0.94 & 1.16 & 1.37 & 1.58 & 1.79 & 2 \\
\hline Trim (+ve by stern) cm & 0 & 0 & 0 & 0 & 0 & 0 & 0 & 0 & 0 & 0 \\
\hline WL Length cm & 0 & 21.88 & 27.89 & 30.6 & 32.4 & 33.78 & 34.89 & 35.84 & 36.66 & 37.34 \\
\hline $\begin{array}{c}\text { Beam max extents on } \\
\text { WL cm }\end{array}$ & 0 & 0.87 & 6.76 & 10.58 & 10.65 & 10.73 & 10.8 & 10.87 & 10.95 & 11.02 \\
\hline Wetted Area cm^2 & 0 & 11.73 & 80.89 & 155.29 & 218.24 & 268.78 & 309.74 & 342.54 & 367.57 & 387.42 \\
\hline Waterpl. Area $\mathrm{cm}^{\wedge} 2$ & 0 & 11.57 & 79.78 & 151.97 & 209.96 & 253.78 & 286.13 & 308.24 & 320.27 & 325.73 \\
\hline Prismatic coeff. $(\mathrm{Cp})$ & 0 & 0.753 & 0.426 & 0.402 & 0.447 & 0.496 & 0.537 & 0.57 & 0.595 & 0.613 \\
\hline Block coeff. (Cb) & 0 & 0.242 & 0.197 & 0.223 & 0.308 & 0.376 & 0.429 & 0.471 & 0.503 & 0.526 \\
\hline $\begin{array}{l}\text { Max Sect. area coeff. } \\
(\mathrm{Cm})\end{array}$ & & 0.5 & 0.5 & 0.581 & 0.71 & 0.776 & 0.814 & 0.839 & 0.856 & 0.869 \\
\hline $\begin{array}{c}\text { Waterpl. area coeff. } \\
\text { (Cwp) }\end{array}$ & 0 & 0.605 & 0.423 & 0.47 & 0.608 & 0.7 & 0.759 & 0.791 & 0.798 & 0.791 \\
\hline $\begin{array}{l}\text { LCB from zero pt. (+ve } \\
\text { fwd) } \mathrm{cm}\end{array}$ & 0 & 10.09 & 10.04 & 10.59 & 11.25 & 12 & 12.73 & 13.39 & 13.95 & 14.38 \\
\hline $\begin{array}{l}\text { LCF from zero pt. (+ve } \\
\text { fwd) } \mathrm{cm}\end{array}$ & 0 & 9.52 & 10.38 & 11.17 & 12.43 & 13.7 & 14.81 & 15.69 & 16.21 & 16.4 \\
\hline $\mathrm{KB} \mathrm{cm}$ & 0 & 0.3 & 0.44 & 0.58 & 0.72 & 0.86 & 0.99 & 1.11 & 1.24 & 1.35 \\
\hline $\mathrm{KG} \mathrm{cm}$ & 2 & 2 & 2 & 2 & 2 & 2 & 2 & 2 & 2 & 2 \\
\hline BMt cm & 0 & 1.5 & 10.68 & 17.96 & 16.7 & 14.21 & 11.92 & 9.88 & 8.11 & 6.8 \\
\hline $\mathrm{BML} \mathrm{cm}$ & 0 & 1573.27 & 415.26 & 266.82 & 189.22 & 147.89 & 123.77 & 107.83 & 94.22 & 80.81 \\
\hline GMt cm & -2 & -0.21 & 9.12 & 16.54 & 15.42 & 13.07 & 10.9 & 8.99 & 7.34 & 6.16 \\
\hline $\mathrm{GML} \mathrm{cm}$ & -2 & 1571.57 & 413.7 & 265.4 & 187.94 & 146.75 & 122.76 & 106.94 & 93.45 & 80.17 \\
\hline $\mathrm{KMt} \mathrm{cm}$ & 0 & 1.79 & 11.12 & 18.54 & 17.42 & 15.07 & 12.9 & 10.99 & 9.34 & 8.16 \\
\hline $\mathrm{KML} \mathrm{cm}$ & 0 & 1573.57 & 415.7 & 267.4 & 189.94 & 148.75 & 124.76 & 108.94 & 95.45 & 82.17 \\
\hline $\begin{array}{c}\text { Immersion }(\mathrm{TPc}) \\
\text { tonne/cm }\end{array}$ & 0 & 0 & 0 & 0 & 0 & 0 & 0 & 0 & 0 & 0 \\
\hline MTc tonne.m & 0 & 0 & 0 & 0 & 0 & 0 & 0 & 0 & 0 & 0 \\
\hline $\begin{array}{c}\mathrm{RM} \text { at } 1 \mathrm{deg}= \\
\text { GMt.Disp.sin(1) kg.cm }\end{array}$ & 0 & 0 & 0 & 0.01 & 0.02 & 0.03 & 0.03 & 0.04 & 0.04 & 0.04 \\
\hline Max deck inclination deg & 0 & 0 & 0 & 0 & 0 & 0 & 0 & 0 & 0 & 0 \\
\hline $\begin{array}{c}\text { Trim angle (+ve by } \\
\text { stern) deg }\end{array}$ & 0 & 0 & 0 & 0 & 0 & 0 & 0 & 0 & 0 & 0 \\
\hline
\end{tabular}

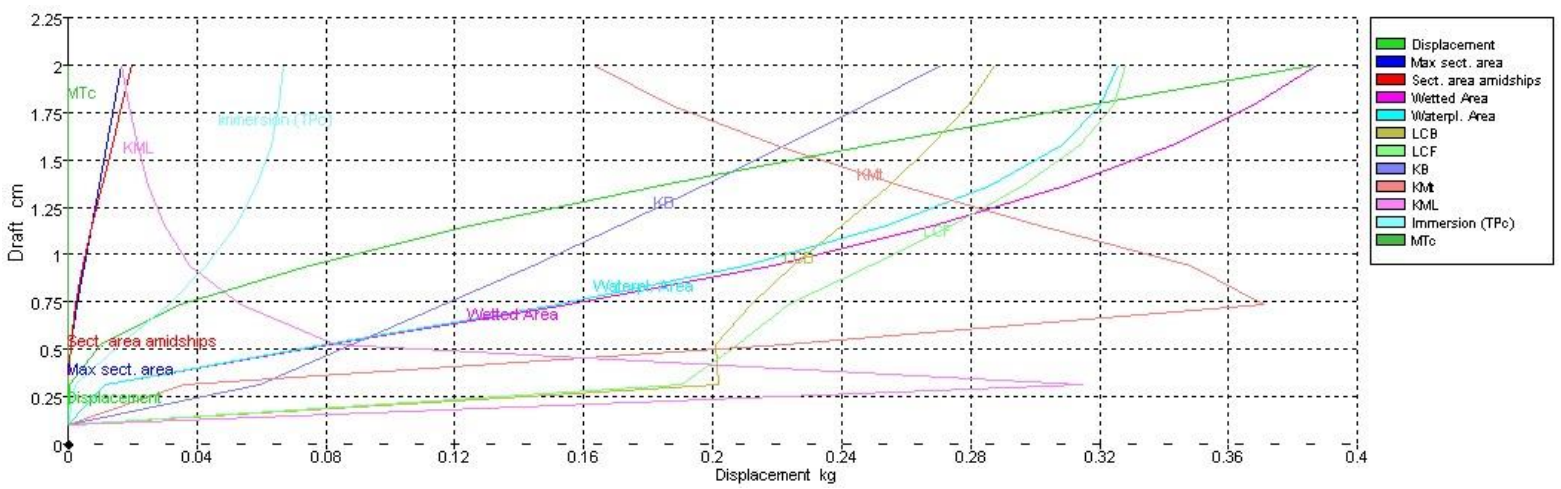

Gambar 6. Kurva Hidrostatik dari Desain Kapal 
Darma et al., Desain dan Manufaktur Mini Circculating Water

\section{Percobaan Olah Gerak Kapal di Circulating Water Channel Tank}

Percobaan ini dilakukan dengan 2 tipe kecepatan yang berbeda, yang pertama

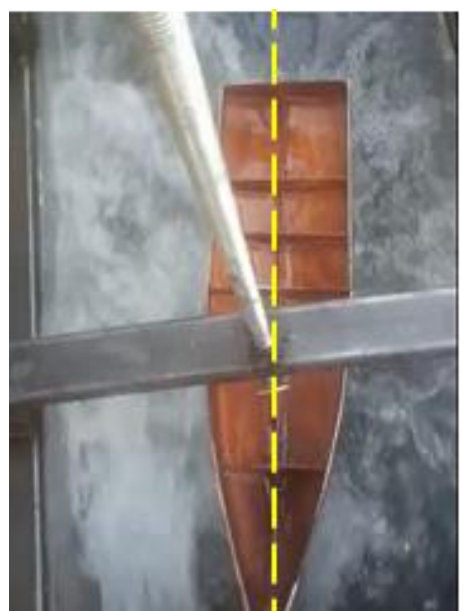

Gambar 7. 2 m/s Time Frame 1

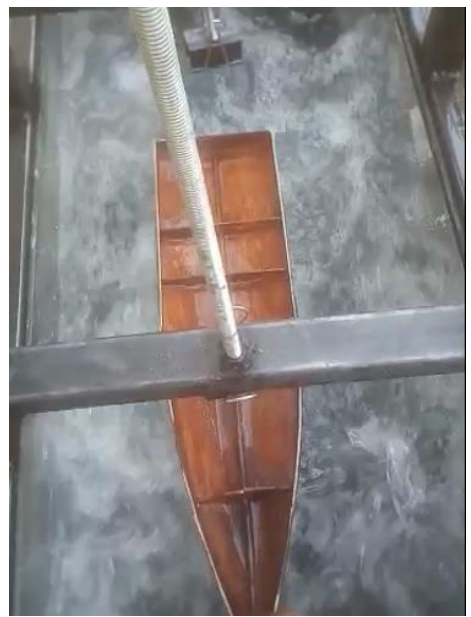

Gambar 9.2 m/s Time Frame 3 adalah kecepatan $2 \mathrm{~m} / \mathrm{s}$ dan yang ke dua adalah $4 \mathrm{~m} / \mathrm{s}$

Kapal model diletakkan di test bed kemudian alat di nyalakan sampai kecepatan $2 \mathrm{~m} / \mathrm{s}$.
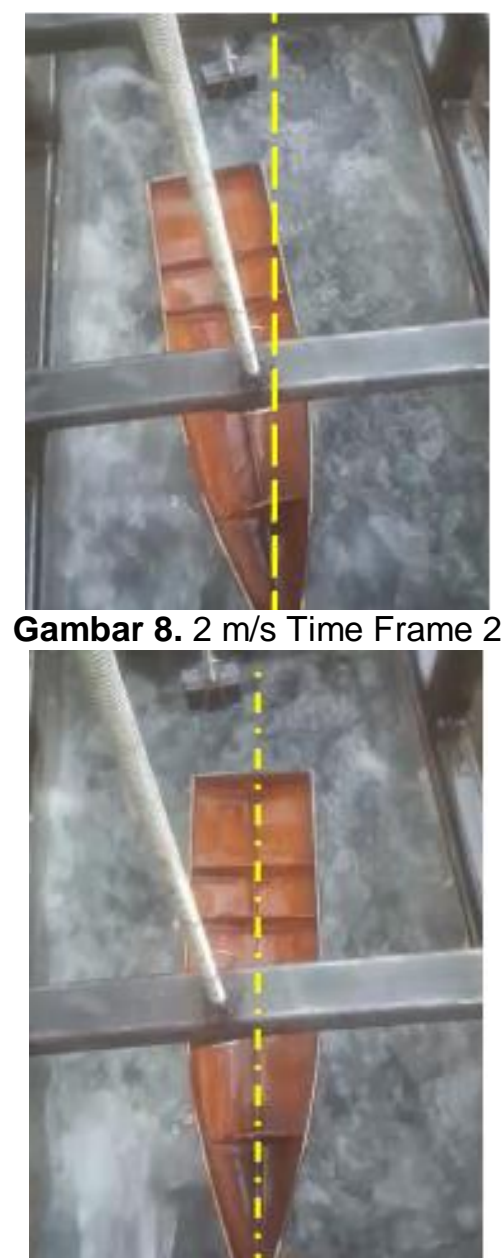

Gambar $10.2 \mathrm{~m} / \mathrm{s}$ Time Frame 4

Seperti yang terlihat pada Gambar 7 sampai pada Gambar 10 kapal model bergerak dinamis dari time frame ke time frame, pada time frame ke satu, posisi kapal pada center line sedangkan pada posisi ke dua kapal bergerak ke arah kiri, dan pada frame ke tiga kapal mulai bergerak kembali ke arah center line. Kondisi ini menunjukkan bahwa aliran air yang di hasilkan oleh Circulating Water Channel Tank adalah selaras.

Kapall model diletakkan di test bed kemudian alat di nyalakan sampai kecepatan $4 \mathrm{~m} / \mathrm{s}$.

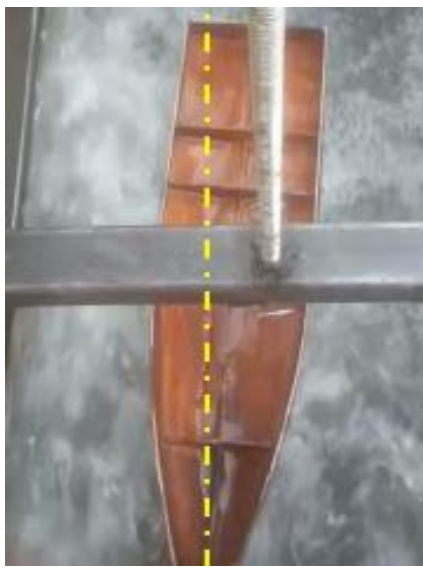

Gambar 11.4 m/s Time Frame 1

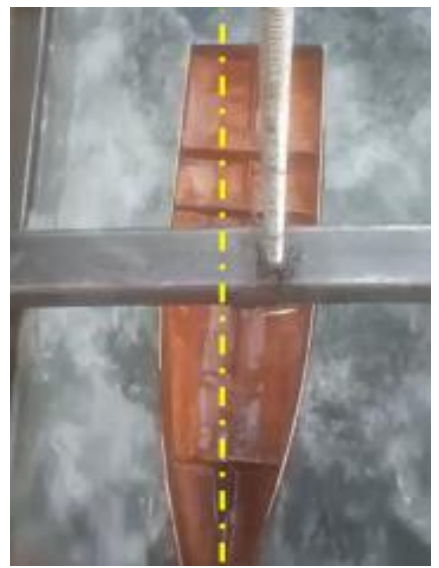

Gambar $11.4 \mathrm{~m} / \mathrm{s}$ Time Frame 2 


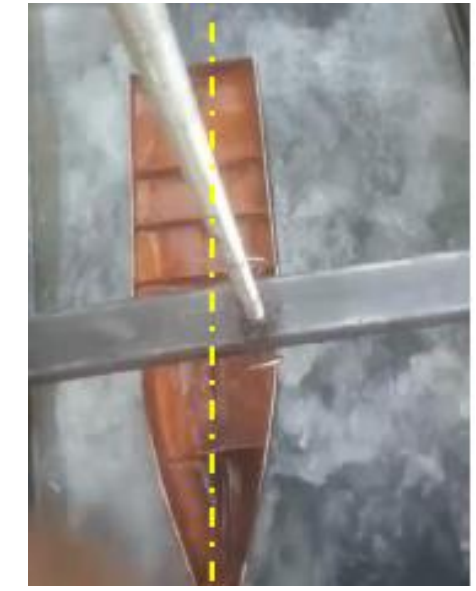

Gambar $11.4 \mathrm{~m} / \mathrm{s}$ Time Frame 3

Seperti yang terlihat pada Gambar 11 sampai pada Gambar 14 kapal model bergerak dinamis dari time frame ke time frame, pada time frame ke satu, posisi kapal pada arah kanan sedangkan pada posisi ke dua kapal bergerak ke arah kiri, dan pada frame ke tiga kapal berada pada posisi center line, begitu pula pada frame keempat. Kondisi ini menunjukkan bahwa kapal yang di desain bergerak lebih tenang jika di gerakkan pada kecepatan yang tinggi, hal ini juga membuktikan bahwa desain yang di buat adalah cocok untuk kapal cepat atau speed boat.

\section{KESIMPULAN DAN SARAN}

Dari hasil penelitian dapat di simpulkan bahwa aliran air yang di hasilkan oleh Circulating Water Channel Tank memiliki aliran yang selaras, desain kapal yang di buat sangat cocok untuk kapal jenis speed boat, simulasi dengan menggunakan software mampu untuk membuat alat lebih baik karena pemilihan material bisa sangat tepat karena rekomendasi software. Adapun saran yang dapat diberikan berdasarkan hasil kegiatan ini adalah perlu adanya pengembangan lebih lanjut terkait pengembangan kapasitas yang lebih besar yang nantinya alat ini bisa digunakan untuk pengujian renewable energy jenis micro hydro.

\section{UCAPAN TERIMAKASIH}

Ucapan terima kasih disampaikan kepada DIPA Politeknik Negeri Banyuwangi Tahun 2019 atas didanainya program Penelitian Dosen Pemula (PDP) tahun anggaran 2019.

\section{DAFTAR PUSTAKA}

Kawashima, T., \& Osawa, Y. (1991). On the circulating tank newly bult at the National Research Institute of Fisheries Engineering. Bulletin of National

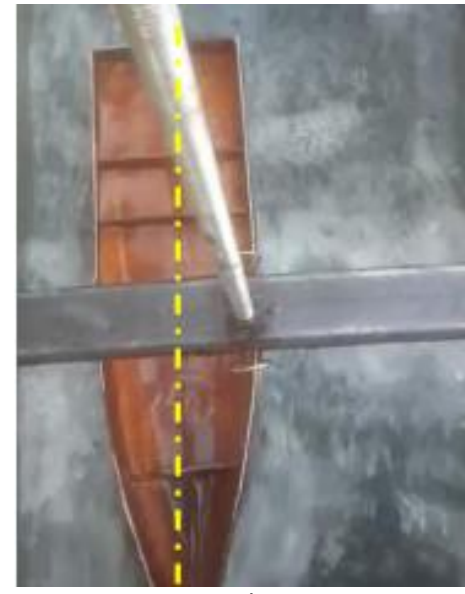

Gambar 11.4 m/s Time Frame 4

Research Institute of Fisheries Engineering (Japan).

Panah, A.E. (2017). Design and Build a Water Channel for a Fluid Dynamics Lab Nature. American Society for Engineering Education, ID \#19026. 2017 Pennsylvania State University Berks

Myers, L., \& Galloway, P. (2011). Operational issues surrounding the use of towing tanks for performance quantification of marine current energy converters. Sustainable energy Research Group, Faculty of Engineering and the Environment University of Southampton, SO171BJ, United Kingdom.

Aditama, P., Sunarintyas, S., \& Widjijono, W. (2015). Pengaruh Jenis dan Volumetrik Fiber terhadap Kekuatan Transversal Reparasi Plat Resin Akrilik. Majalah Kedokteran Gigi Indonesia, 1(1), 102108 